\section{Immunohistochemical identification of resistin in the uterus of ewes subjected to different diets: Preliminary results}

\author{
Cecilia Dall'Aglio, ${ }^{1}$ Paola Scocco, ${ }^{2}$ \\ Margherita Maranesi, ${ }^{1}$ Linda Petrucci, ${ }^{1}$ \\ Gabriele Acuti, ${ }^{1}$ Elena De Felice, ${ }^{2}$ \\ Francesca Mercati ${ }^{1}$
}

${ }^{1}$ Department of Veterinary Medicine,

University of Perugia

${ }^{2}$ School of Biosciences and Veterinary

Medicine, University of Camerino, Italy

\begin{abstract}
Resistin is a polypeptide hormone of the adipokine-family, primarily, but not exclusively, produced by the adipose tissue. Recent studies suggested that resistin may affect the male and female reproductive activity. The study aim was to immunohistochemically evaluate the presence and distribution of resistin in the ovine uterus. Uterine samples were collected from two groups of ewes at the end of an experimental trial during which the animals of the first group (CTRL) were fed only by grazing while those of the second one (EXP) were supplemented with barley and corn. Using a monoclonal antibody against resistin, tested by Western Blot, the immunopositive reaction was identified in the cytoplasm of epithelial lining cells and uterine glands. The endogenous production of resistin seemed to be affected by different diet, as evidenced by staining differences between the CTRL and EXP groups. Our findings support the existence of a peripheral resistin system in the sheep uterus. It is possible that this system is involved in the functionality of the uterus, which is also affected by the animal's nutritional status.
\end{abstract}

\section{Introduction}

Resistin, a recently discovered polypeptide hormone that is a component of the adipokine-family, is produced primarily, but not exclusively, by the adipose tissue. In this regard, it is well known that many other hormones known as adipokines are produced not only by white adipose tissue but also by other organ tissues, where they probably play different roles, always linked to the functionality of the tissue/organ where they are evidenced. ${ }^{1-6}$ Resistin is an adipose tissue-specific secretory factor that in humans is encoded by the RETN gene. ${ }^{7}$ The first study considering resistin as an adipokine was on mice, in which the molecule induced resistance to insulin (its name is most likely linked to this particular action); hence, it was perceived as a potential and dangerous link between obesity and diabetes. ${ }^{8}$ More recent studies have shown that resistin mRNA is also present in other tissues of many species. ${ }^{9-12}$ The influence of nutritional status was also considered in the genetic expression of resistin: chronic restriction of food markedly influenced the resistin levels with a strong down-regulation. ${ }^{11}$ Recently, some studies have suggested that resistin could affect male and female reproductive activity. ${ }^{13-15}$ For example, resistin mRNA and protein levels were determined in endometrial tissue from women with or without endometriosis. ${ }^{16}$ Moreover, some research data linked the serum level of resistin to pathological situations of the genital tract, for example polycystic ovary syndrome, known to be linked to hyper-insulinemia and insulin resistance. ${ }^{17,18}$ A recent study demonstrated the presence of resistin in ovarian granulosa cells of cows: resistin is able to modulate steroidogenesis and cellular proliferation, suggesting that it could be considered a metabolic signal for the control of reproductive activity. ${ }^{19}$ To our knowledge, little has been published on the presence and distribution of resistin produced in the uterus of domestic animals, nor have there been studies reporting on the influence of diet in the expression of this adipokine in these animal species. Therefore, we decided to investigate the presence of this molecule in the uterus of sheep, using immunohistochemical techniques. The choice of sheep was related to the strong tradition of sheep rearing in some rural areas of central Italy, where the experimental trial was performed as part of a wider study to achieve sustainable management of grassland productive ecosystems that are subject to increasing drought stress linked to climate change, a trend that has been affecting herbage features, carrying capacity and animal welfare. ${ }^{20,21}$ Indeed, the pasture vegetative cycle comprises two phases, the first from spring to the pasture maximum flowering $(\mathrm{MxF})$, and the second during the summer as the pasture dries and reaches maximum dryness (MxD). Due to climatic change, the summer aridity has been increasing, such that the $\mathrm{MxF}$ moment arrives sooner and the period between $\mathrm{MxF}$ and $\mathrm{MxD}^{20}$ is shortened, thus reducing the amount of food available to the animals. Therefore, being the pasture $\mathrm{MxD}$ moment corresponding to the mating period for the animals grazing in the studied area, summer aridity may bear negatively on the animals' reproductive per-
Correspondence: Margherita Maranesi, Department of Veterinary Medicine, University of Perugia, Via San Costanzo 4, 06126 Perugia, Italy.

Tel. +39.075.5857642 - Fax +39.075.5857631. E-mail: margherita.maranesi@unipg.it

Key words: Sheep; resistin; immunohistochemistry; uterus; diet.

Contributions: PS, experimental trial organization; CD, FM, immunohistochemical studies; MM, LP, Western Blot evaluation; GA, following of the animals' nutritional status; $\mathrm{CD}$, PS, MM, manuscript drafting; EDF, manuscript critical revision. All authors revised the manuscript final draft for publication.

Funding: This research was funded by the "Ricerca di Base 2015, Università degli Studi di Perugia" grant assigned to the project "Studio delle adipochine apelina e resistina nell'apparato genitale femminile di pecore allevate su pascoli a differente valore nutrizionale", Scientific Coordinator Prof. Cecilia Dall'Aglio.

Acknowledgments: The authors wish to thank Dr. Paola Coliolo for her excellent technical assistance and Ms Sheila Beatty for editing the English text.

Received for publication: 16 February 2019. Accepted for publication: 15 April 2019.

This work is licensed under a Creative Commons Attribution-NonCommercial 4.0 International License (CC BY-NC 4.0).

(C) Copyright: the Author(s), 2019

Licensee PAGEPress, Italy

European Journal of Histochemistry 2019; 63:3020 doi:10.4081/ejh.2019.3020

formance. ${ }^{22-24}$ To compensate the negative effects of increasing summer aridity, we explored the possible benefits of providing supplemental feed to sheep.

\section{Materials and Methods}

In the experiment, two homogeneous groups (25 subjects for each group) of Comisana $\mathrm{x}$ Appenninica adult female sheep were free to graze on the pasture during the first pasture phase. Then, during the second phase the first group had grazing alone on pasture (CTRL), while the second group (EXP) also received $600 \mathrm{~g} /$ day/head of barley and corn (1:1). At the pasture $\mathrm{MxD}, 5$ animals for each group, intended for human consumption, were slaughtered in accordance with art. 29 of the Council Regulation (EC) No. 1099/2009 on the protection of animals at the time of killing under law no. 333/98. The experimental 
procedures were approved by the Ministry of Health (no. of approval 95/2018-PR).

The collected uterine samples were stored at $-20^{\circ} \mathrm{C}$ for Western Blot (WB) evaluation, or fixed by immersion in $4 \%$ formaldehyde in phosphate-buffered saline solution ( $\mathrm{pH} 7.4, \mathrm{PBS}$ ) for $24 \mathrm{~h}$ at room temperature and then dehydrated and routinely embedded in paraffin for immunohistochemistry (IHC). To perform WB, total proteins were extracted from $50 \mathrm{mg}$ of uterine samples and processed as previously described. ${ }^{25}$ In the specific step, primary mouse monoclonal antibody antiresistin (1:2000; sc-376336; Santa Cruz biotechnology, Santa Cruz, CA, USA), and a secondary biotinylated goat anti-mouse $\mathrm{IgG}$ (1:2000; BA-BA-9200, Vector Labs, Burlingame, CA, USA) were used. To perform IHC, dewaxed and re-hydrated uterine 5 $\mu \mathrm{m}$ thick sections were microwaved three times for $5 \mathrm{~min}$ each at $750 \mathrm{~W}$ in $10 \mathrm{mM}$ citric acid ( $\mathrm{pH}$ 6.0). Subsequent steps were performed at room temperature in a moist chamber. Sections, after incubation with normal goat serum for $30 \mathrm{~min}$ were incubated overnight with the primary mouse monoclonal antibody anti-resistin (1:100 in PBS). Next day, sections were incubated with the secondary biotinylated goat anti-mouse IgG (1:200 in PBS) antibody for $30 \mathrm{~min}$ and then with the avidin-biotin-peroxidase complex (1:50:1 in PBS; ABC Elite Kit, PK-6200, Vector Labs) for further $30 \mathrm{~min}$. Each incubation was preceded and followed by a PBS washing. Incubation with diaminobenzidine solution (DAB, SK-4100, Vector Labs) (5-10 min) evidenced the immunopositive reaction. Finally, the sections were counterstained with Mayer's haematoxylin. Sections in which the primary antibody was omitted and/or substituted by pre-immune mouse-globulin were used for the negative control of unspecific staining. All tissue analyses were carried out on randomly selected slides by two independent investigators who were unaware of the treatments, using a light microscope (Nikon Eclipse E800, Nikon Corporation, Tokyo, Japan) connected to a digital camera (Dxm

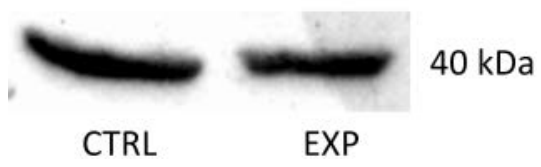

Figure 1. Immunoblot showing resistin in uterine lysate of two different ewes belonging to CTRL and EXP groups. Total protein extracts were separated by SDS-PAGE and analysed by immunoblotting with an anti-resistin specific antibody.
1200 Nikon digital camera). The images were processed using an image analysis system (Lucia, Laboratory Imaging Ltd., Praha, Czech Republic). The settings for image capture were standardized by subtracting the background signals obtained from the matched tissue sections which had not reacted with the primary antibodies and which were used as immunohistochemical controls. Based on these considerations, the intensity of the staining was graded in arbitrary units as follows: negative $(-)$, weak $(+)$, strong $(++)$.

\section{Results}

By WB, a single band at approximately $40 \mathrm{kDa}$, was detected in uterine samples of CTRL and EXP groups (Figure 1). Immunohistochemical procedures showed specific staining for resistin in the cytoplasm of cells from the uterine glands and the epithelial lining (Figure 2 a-c). The immuno- positivity involved the whole cytoplasm, though it seemed more evident in the supranuclear region of the cells (Figure $2 \mathrm{a}, \mathrm{c}$ ). A positive immunoreaction for resistin was also evident in the cytoplasm of smooth muscle cells at both vascular (Figure 2d) and myometrium levels. Immuno-positive reaction was not observed in other uterine structures and in the sections used as controls for the specificity of the reaction (inserts in Figure 2 a,b). Comparing the two analysed animal groups (CTRL and EXP), in the epithelial lining samples, no difference was observed in the intensity of immunolabeling for resistin, which appeared weak. Instead, in the uterine gland samples, variations in the immunopositivity were observed. In particular, strong intensity was observed in the uterine gland samples from the EXP animals, while the immunopositivity for resistin appeared less intense in the samples from the CTRL animals. The results are summarized in Table 1 .

Table 1. Resistin-immunopositivity in sheep uterine structures.

\begin{tabular}{lccc} 
& Epithelial lining & Uterine glands & Smooth muscle \\
CTRL group & + & + & + \\
EXP group & + & ++ & + \\
\hline
\end{tabular}
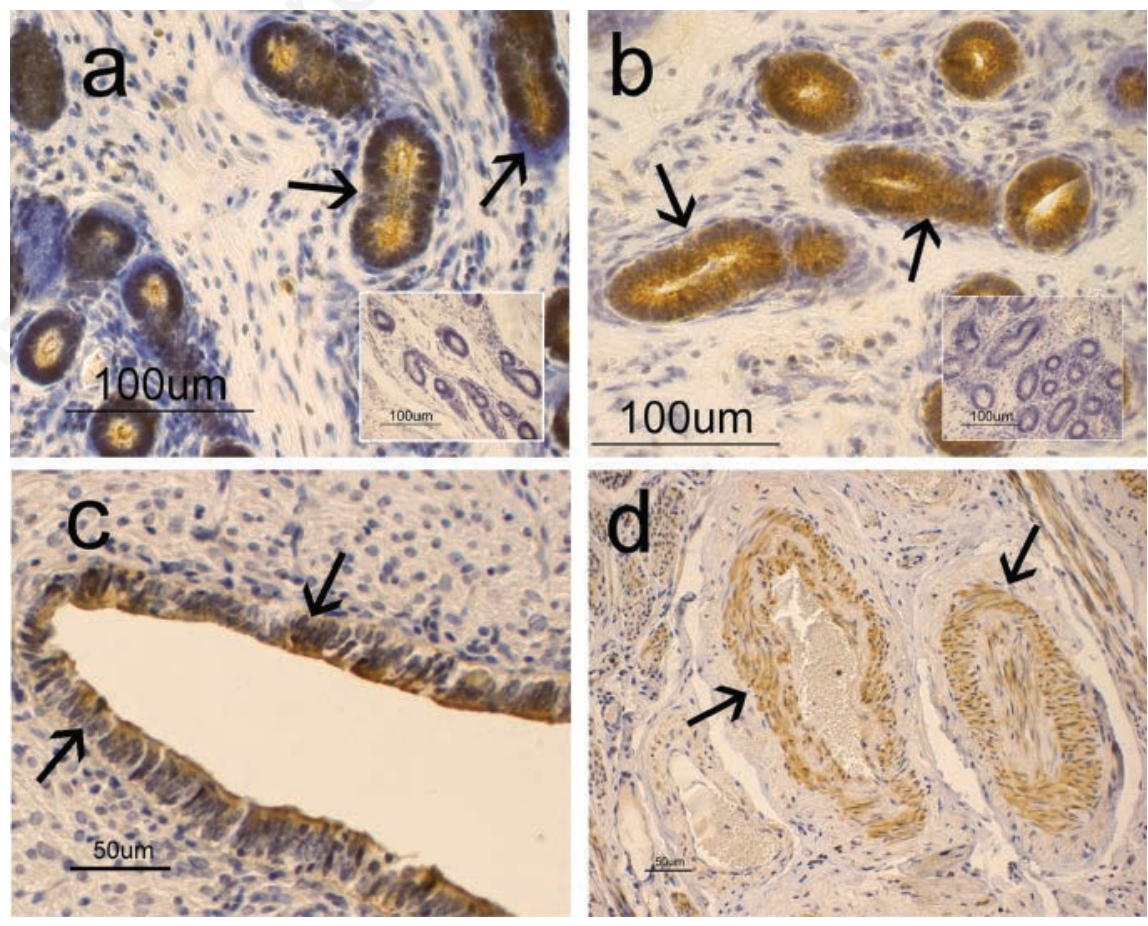

Figure 2. Resistin-immunohistochemistry aspects in the uterus of sheep: in a) and b) immunopositivity is localized in the cytoplasm of uterine glandular cells (arrows) with a stronger intensity in EXP group (b), compared to CTRL group (a). a) Immunopositivity seems to be mainly localized in the supranuclear (arrows) cytoplasm of the uterine glandular cells; c) immunopositivity is localized in the supranuclear (arrows) cytoplasm of the epithelial-lining cells; d) immunopositivity is localized in the muscle cells of arterial vessels (arrows). 


\section{Discussion}

These findings suggest that the food supplementation had an effect on resistin production in the sheep uterine glands, while this does not seem in the epithelial lining. It can be speculated that food supplementation allows to a better animal body status; therefore, also resistin production by uterine glands enhances. The supranuclear location of resistin binding patterns allows us to hypothesize that resistin could have an autocrine action ${ }^{26-28}$ stimulating the uterine gland secretory activity, in addition to a paracrine action as trophic factor towards spermatozoa and/or embryos. However, other studies will be needed to define the role of the resistin system more precisely. It is likely that resistin action is affected by the participation of other molecules, as is the case for insulin, whose action is modulated by glucagon, nesfatin, leptin and resistin. ${ }^{29-32}$

This immunohistochemical study identified resistin positive cells in the uterus of sheep, supporting the existence of a peripheral resistin system also in the reproductive apparatus of this animal species. There are no previous studies in this species on the resistin WB identification. The single band here detected at $40 \mathrm{kDa}$ confirmed the antibody specificity used for IHC. The difference with $34 \mathrm{kDa}$ weight of human resistin antibody, also considering the homology of $70 \%$ between human and sheep resistin sequence, may be ascribed to the difference between the two species. To the best of our knowledge, this is the first study to demonstrate the presence of resistin in the uterus of a species of domestic animals, showing that this adiponectin is produced by the uterus of these animals and that its production can be modified by changes in nutritional status, an observation that strengthens the link between nutritional status and reproductive activity. This finding is particularly important for the Apennine area, where the natural pastures provide the summer trophic resources needed for ewes to attain a suitable body status for sustaining pregnancy, which, in turn, is a key factor for the sustainability of local farms. ${ }^{21}$

\section{References}

1. Bado A, Levasseur S, Attoub S, Kermorgant S, Laigneau JP, Bortoluzzi $\mathrm{MN}$, et al. The stomach is a source of leptin. Nature 1998;394:790-3.

2. Brément T, Cossec C, Roux C, Knol AC, Dréno B, Khammari A, et al. Expression of three adipokines (Adiponectin, Leptin and Resistin) in normal canine skin: a pilot study. J Comp Pathol 2018;167:82-90 .

3. Cappai MG, Dall'Aglio C, Sander SJ, Ratert C, Dimauro C, Pinna W, et al. Different physical forms of one diet fed to growing pigs induce morphological changes in mandibular glands and local leptin $(\mathrm{Ob})$ production and receptor (ObR) expression. J Anim Physiol Anim Nutr 2016;100:1067-72.

4. Mercati F, Maranesi M, Dall'Aglio C, Petrucci L, Pasquariello R, Tardella FM, et al. Apelin system in mammary gland of sheep reared in semi-natural pastures of the Central Appennines. Animals 2018;8:pii:E223.

5. Mercati F, Dall'Aglio C, Timperi L, Scocco P, De Felice E, Maranesi M. Epithelial expression of the hormone leptin by bovine skin. Eur J Histochem 2019;63:2993.

6. Dall'Aglio C, Mercati F, Pascucci L, Bazzucchi C, Ceccarelli P. Immunohistochemical evidence of leptin and its receptor in the carpal glands of domestic pigs and wild boar. Vet Dermatol 2015;26:46-8.

7. Wang H, Chu WS, Hemphill C, Elbein SC. Human resistin gene: molecular scanning and evaluation of association with insulin sensitivity and type 2 diabetes in Caucasians. J Clin Endocrinol Metab 2002;87:2520-4.

8. Steppan CM, Bailey ST, Bhat S, Brown EJ, Banerjee RR, Wright CM, et al. The hormone resistin links obesity to diabetes. Nature 2001;409:307-12.

9. Nogueiras R, Gallego R, Gualillo O, Caminos JE, García-Caballero $\mathrm{T}$, Casanueva FF, et al. Resistin is expressed in different rat tissues and is regulated in a tissue- and gender-specific manner. FEBS Lett 2003;548:21-7.

10. Morash BA, Wilkinson D, Ur E, Wilkinson M. Resistin expression and regulation in mouse pituitary. FEBS Lett 2002;526:26-30.

11. Savage DB, Sewter CP, Klenk ES , Segal DG, Vidal-Puig A, Considine RV, et al. Resistin/Fizz3 expression in relation to obesity and peroxisome proliferator-activated receptor-gamma action in humans. Diabetes 2001;50:2199-202.

12. Yura S, Sagawa N, Itoh H, Kakui K, Nuamah MA, Korita D, et al. Resistin is expressed in the human placenta. J Clin Endocrinol Metab 2003;88:1394-7.

13. Tovar S, Nogueiras R, Tung LY, Castañeda TR, Vázquez MJ, Morris A, et al. Central administration of resistin promotes short-term satiety in rats. Eur J Endocrinol 2005;153:1-5.

14. Brown R, Wiesner G, Ur E, Wilkinson M. Pituitary resistin gene expression is upregulated in vitro and in vivo by dex- amethasone but is unaffected by rosiglitazone. Neuroendocrinology 2005;81: 41-8.

15. Nogueiras R, Barreiro ML, Caminos JE, Gaytán F, Suominen JS, Navarro VM, et al. Novel expression of resistin in rat testis: functional role and regulation by nutritional status and hormonal factors. J Cell Sci 2004;117:3247-57.

16 Oh YK, Ha YR, Yi KW, Park HT, Shin $\mathrm{JH}, \mathrm{Kim} \mathrm{T}$, et al. Increased expression of resistin in ectopic endometrial tissue of women with endometriosis. Am J Reprod Immunol 2017;78:e12726.

17. Panidis D, Koliados G, Kourtis A, Farmakiotis D, Mouslech T, Rousso D. Serum resistin levels in women with polycystic ovary syndrome. Fertil Steril 2004;81:361-6.

18. Carmina E, Orio F, Palomba S, Cascella T, Longo RA, Colao AM, et al. Evidence for altered adipocytes function in polycystic ovary syndrome. Eur J Endocrinol 2005;152:389-94.

19. Maillard V, Froment P, Ramé C, Uzbekova S, Elis S, Dupont J. Expression and effect of resistin on bovine and rat granulosa cell steroidogenesis and proliferation. Reproduction 2011;141:467-79.

20. Scocco P, Piermarteri K, Malfatti A, Tardella FM, Catorci A. Increase of drought stress negatively affects the sustainability of extensive sheep farming in sub-Mediterranean climate. J Arid Envir 2016;128:50-8.

21. Scocco P, Piermarteri K, Malfatti A, et al. Effects of summer rainfall variations on sheep body state and farming sustainability in sub-mediterranean pastoral system. Span J Agric Res 2016; 14:1-4.

22. Scocco P, Mercati F, Brusaferro A, Ceccarelli P, Belardinelli C, Malfatti A. Keratinization degree of rumen epithelium and body condition score in sheep grazing on Brachipodium rupestre. Vet Ital 2013;49:211-7.

23. Scocco P, Mercati F, Tardella FM, Catorci A. Increase of forage dryness induces differentiated anatomical response in the sheep rumen compartments. Microsc Res Tech 2016;79:738-43.

24. Scocco P, Rivaroli S, Mercati F, Tardella FM, Malfatti A, De Felice E, et al. Anatomy for economy: starting from the rumen keratinization degree to enhance the farm income. Economia Agro-Alimentare 2018;20:261-72.

25. Maranesi M, Petrucci L, Leonardi L, Bufalari A, Parillo F, Boiti C, et al. Kisspeptin/kisspeptin receptor system in pseudopregnant rabbit corpora lutea: presence and function. Sci Rep 2019;9:5044. 
26. Jiang C, Zhang H, Zhang W, Kong W, Zhu Y, Zhang $\mathrm{H}$, et al. Homocysteine promotes vascular smooth muscle cell migration by induction of the adipokine resistin. Am J Physiol Cell Physiol 2009;297:1466-76.

27. McTernan PG, Fisher FM, Valsamakis G, Chetty R, Harte A, McTernan CL, et al. Resistin and type 2 diabetes: regulation of resistin expression by insulin and rosiglitazone and the effects of recombinant resistin on lipid and glucose metabolism in human differentiated adipocytes. J Clin Endocrinol Metab 2003; 88:6098-106.
28.Pravenec M, Mlejnek P, Zidek V, Landa V, Šimáková M, Šilhavý J, et al. Autocrine effects of transgenic resistin reduce palmitate and glucose oxidation in brown adipose tissue. Physiol Genomics 2016;48:420-7.

29. Figlewicz DP, Benoit SC. Insulin, leptin, and food reward: update 2008. Am J Physiol Regul Integr Comp Physiol 2009;296:9-19.

30. Brecchia G, Bonanno A, Galeati G, Federici C, Maranesi M, Gobbetti A, et al. Hormonal and metabolic adaptation to fasting: effects on the hypothalamicpituitary-ovarian axis and reproductive performance of rabbit does. Domest Anim Endocrinol 2006;31:105-22.

31. Foo KS, Brauner H, Ostenson CG,Broberger C. Nucleobindin-2/nesfatin in the endocrine pancreas: distribution and relationship to glycaemic state. J Endocrinol 2010;204:255-63.

32. Gatta C, De Felice E, D'Angelo L, 32. Gatta C, De Felice E, D'Angelo L, Maruccio L, Leggieri A, Lucini C et al. The case study of Nesfatin-1 in the pancreas of Tursiopstruncatus. Front Physiol 2018;9:1845. 